Revue européenne des sciences sociales

European Journal of Social Sciences

XLII-129 | 2004

La sociologie durkheimienne : tradition et actualité

\title{
The rise of social science disciplines in France
}

Johan Heilbron

\section{OpenEdition}

\section{Journals}

Electronic version

URL: http://journals.openedition.org/ress/394

DOI: $10.4000 /$ ress.394

ISSN: $1663-4446$

\section{Publisher}

Librairie Droz

\section{Printed version}

Date of publication: 1 March 2004

Number of pages: 145-157

ISBN: 2-600-00941-8

ISSN: 0048-8046

Electronic reference

Johan Heilbron, "The rise of social science disciplines in France », Revue européenne des sciences sociales [Online], XLII-129 | 2004, Online since 01 March 2004, connection on 30 April 2019. URL http://journals.openedition.org/ress/394 ; DOI : 10.4000/ress.394 


\section{THE RISE OF SOCIAL SCIENCE DISCIPLINES IN FRANCE}

Studies on the history and the institutionalization of sociology in France, many of them coordinated by Philippe Besnard, have developed by moving forward in time. Taking off in the 1970s with Steven Lukes' biography of Durkheim, Victor Karady's editions of Durkheim and Mauss and several research projects, Philippe Besnard edited the series of well known special issues of the Revue française de sociologie about sociology and related disciplines, ranging from the end of the nineteenth century until the rebirth of French sociology after the Second World War $^{1}$. Relatively few attempts, however, have been made to move backward in time and to examine the configuration of the social sciences in France prior to their establishment as university disciplines. In this article, I will briefly look at earlier developments and propose a general interpretation of the development of the social sciences in nineteenth century France. This perspective suggests a rather different view of the institutionalization of sociology than is commonly held and raises some interesting comparative questions as well.

For the major part of the nineteenth century, French social science was concentrated in and around a single institution that is hardly ever mentioned in the standard histories of the social sciences. This institution, the Académie des sciences morales et politiques, was inaugurated in 1832 as the official centre for moral and political studies under the constitutional regime of the July Monarchy (1830-48). The Academy remained the dominant institution for the social sciences in France until the end of the nineteenth century, when it lost its hegemonic position to a variety of university disciplines on the one hand, and to new forms of administrative and political expertise on the other hand. Around 1900 it was no longer possible to pursue a scholarly career while simultaneously having important political or administrative responsibilities, thus separating what the Academy had typically combined for many decades.

As a meeting place for high civil servants and academics, the Academy embodied the state liberalism of the constitutional monarchy of Louis-Philippe ${ }^{2}$. The vast majority of the académiciens belonged to the urban and more liberal factions of the notables, who opposed the rising demands of worker movements as well as the politics of conservative Catholics and nostalgic noblemen. On the

The first of this series was the special issue about Durkheim in 1976 (nr 2) of the Revue française de sociologie edited by Philippe Besnard; the issue on postwar French sociology was published in 1991 (nr.3). Between the two there were special issues about the durkheimians (1979), Durkheim's competitors (1981) and about the interwar period (1985).

2 Lucien Jaume, L'individu effacé, ou le paradoxe du libéralisme français, Paris, Fayard, 1997. 
basis of a largely secular, juste milieu orientation, the academicians read memoirs, discussed policy matters, organised prize contests about pressing moral issues, published proceedings with philosophical, economic, legal and political studies, and commissioned research into the conditions of the urban poor and the working classes, which were perceived as a dangerous force.

Although hardly any of these academic studies have gained a place in the canon of the social sciences, the Academy undoubtedly fulfilled a crucial role in the early development of the social sciences. Not only was it one of the very first institutions in the world officially devoted to this relatively new scientific domain, it provided an infrastructure for these disciplines, thus concentrating, coordinating and controlling previously dispersed efforts. The historical significance of the Academy is well illustrated by the fact that, by the end of the nineteenth century, representatives of the emerging university disciplines often conceived their work in opposition to the Academy of moral and political sciences. The emergence of psychology, sociology and political economy as university disciplines in France is in fact best understood as a break with the practices and the doctrines of the Academy. The reason why the Academy has disappeared almost completely from the collective memory is indeed that the generation of university pioneers has succeeded all too well.

\section{THAT GREAT SCIENCE OF GOVERNMENT}

The Academy had its immediate origins in a former 'class' of the Institut de France, which in 1795 replaced the abolished academies of the old regime. The second class, devoted to the moral and political sciences, lasted barely eight years and did not survive Napoleon's rise to power. Plans for such an official centre for the political and administrative sciences had been much older. From the end of the seventeenth century onwards, various projects had been launched to create some sort of official body for the study of policy matters (political economy, political arithmetic, law, cameral sciences and the like), but all these proposals were obstructed by the absolutist monarchy for fear of political opposition. In this highly sensitive domain, governmental services were consistently preferred to an official Academy, which would have to be granted a certain degree of independence, which would publish accessible proceedings, and which would elect its own members. Governmental services, on the other hand, were directly subjected to state officials and produced knowledge that generally remained confidential ${ }^{3}$.

When after the Revolution the Institut de France took over the role of the former academies, the plans for an independent Academy for the moral and political sciences finally materialised. Members of the 'second class' of the national institute played a key-role in debates about educational reform, legislation, health policy and economic issues. Among them there were philosophers, political economists, jurists, historians and ethnographers, all of who were - in different ways - committed to the objective of stabilizing the revolutionary changes. By 1803,

For a more extensive treatment of the early history see my The Rise of Social Theory, Cambridge, Polity Press, 1995. 
however, Napoleon suppressed the second class, and its members were dispersed over the other classes of the Institut ${ }^{4}$.

After the authoritarian Napoleonic Empire and the Bourbon Restoration (1815-30), the Academy was officially re-established. Its founding members were intellectuals who had belonged to the liberal wing of the opposition movement under the Restoration, notably the historian François Guizot and the young philosopher Victor Cousin. The general aim of the liberals was to put an end to the battles between conservative defenders of the absolutist monarchy and revolutionary republicans. In their view only a moderate, constitutional regime could provide a stable basis for the future of France. When Guizot became a Minister in 1830, he proposed the King to re-establish the Academy as 'an indirect but useful support' to the new government. The moral and political sciences, according to Guizot, had become an indispensable intellectual force. In no other era and no other nation had they acquired such an importance and such a public esteem. For the first time in history, furthermore, they had become 'truly scientific': founded on 'certain facts,' they promised to be applicable and useful. Since the new regime guaranteed the «union of the interests of the government with those of society», the moral and political sciences could henceforth «sustain what they had previously shaken $»^{5}$.

Guizot's proposal unambiguously aimed at the reconciliation of intellectual reflection with the political and administrative needs of the government. In that sense the Academy continued a long tradition of administrative research and reflections on the art of statecraft, which in France had been carried by mainly the noblesse de robe and reform minded state officials like Turgot ${ }^{6}$. Contrary to its predecessors, however, the new Academy turned out to be a lasting achievement. Up to this day, it represents the social sciences in its most official guise, remaining close to the centres of power by instituting a regular exchange between academics and high state officials and other dignitaries. This semi-official think tank à la française was initially comprised of five sections : philosophy, morals, legislation, political economy, and history. Every section had six regular members and a number of correspondents and foreign associates. Among the latter were diplomats and statesmen as well as scholars such as James Mill, Thomas Malthus, and Adolphe Quetelet.

The actual work of the academicians was largely defined by practical needs. Approximately 60 to $80 \%$ of the academic lectures, book reviews and prize contests were, during the years between 1832 and 1860, devoted to practical issues ${ }^{7}$. The

See Jules Simon, Une Académie sous le Directoire, Paris, Calmann Lévy, 1885 ; Martin S. Staum, Minerva's Message. Stabilizing the French Revolution, Montreal, McGill-Queen's University Press, 1996; Jean-Luc Chappey, La Société des Observateurs de l'homme (1799-1804), Paris, Société des études robespierristes, 2002.

5 François Guizot, «Ordonnance du Roi qui rétablit dans le sein de l'Institut royal de France l'ancienne Classe des sciences morales et politiques » (1832), in Académie des sciences morales et politiques, Notices biographiques et bibliographiques, Paris, 1981, pp. XV-XVIII.

- Eric Brian, La mesure de l'État. Géomètres et administrateurs au XVIII siècle, Paris, Albin Michel, 1994.

7 Corinne Delmas, Les rapports du savoir et du pouvoir: l'Académie des sciences morales et politiques de 1832 à 1914, Doctorat de Science Politique, Université de Paris IX-Dauphine, 2000, 
themes most frequently addressed were issues of poverty, crime and public health as related to the working classes. These studies were complemented by statistical surveys of specific populations, which equally informed the local and national elites about the dangers they faced. Other recurrent themes were juridical and economic problems, many of them related to parliamentary commissions. The practical orientation of the Academy was not only linked to its expected role as an 'indirect but useful support' of the government, but also to its membership. Of the five national academies, the Académie des sciences morales et politiques was by far the most political one and the one closest to the state elite. When they were elected to the Academy all members - with a single exception - had at least published one book, which apparently constituted a minimum condition for membership ${ }^{8}$. A vast majority of the members, nearly three quarters, held a political position as deputy, senator or minister, a proportion that was much higher than in the other academies (16\% for the Academy of sciences, $3 \%$ for the Academy of fine arts for example). Only the Académie française came close with $58 \%$ of their members holding a political office. The social background of the academicians reinforced the links to the state: three quarter of the members came from families belonging to the notables, only a minority came from the middle classes (employees, craftsman, shopkeepers) or from families of skilled workers.

Within the general framework of the Academy, there was a division of labour between and within the various sections. The practical issues were mostly dealt with in the sections of morals, legislation and political economy that also had the highest proportion of civil servants among its members. The philosophy and the history section had a higher proportion of scholars and were more often concerned with scholarly issues. The philosophers provided a theoretical orientation for the Academy as a whole, whereas the historians offered a historical perspective on the questions that the Academy dealt with.

One of the most active and prominent members of the Academy was Victor Cousin, the leading figure of the philosophy section and an orator and public figure of great renown. Cousin, a graduate of the Ecole normale supérieure of humble background, had made a name for himself with his Sorbonne lectures of the 1820s. In these lectures he elaborated his spiritualist philosophy, which was eventually taught in every lycée and university in the country, and which implied a firm rejection of the 'materialist' doctrines of the late Enlightenment and the revolutionary period. Since man was a spiritual being, endowed with a soul and a consciousness, the methods of the natural sciences were wholly inappropriate. Philosophy was concerned with universal standards of truth, beauty and virtue.

p. 129. See also Sophie-Anne Leterrier, L'institution des sciences morales et politiques 1795 1850, Paris, L'Harmattan, 1995. For additional information: E. Seillière, Une Académie à l'époque romantique, Paris, Ernest Leroux, 1926; C. Lyon-Caen, «Notice historique sur l'Académie des sciences morales et politiques, 1795-1803, 1832-1932», Publications diverses de l'Institut de France, 102, 1934, pp. 65-88. For a bibliography, see R. de Lasteyrie, Bibliographie générale des travaux historiques et archéologiques publiés par les sociétés savantes de la France, Paris, Imprimerie Nationale, 1901, volume III, pp. 536-89. On the archives, see Elise Feller and Jean-Claude Goery, «Les archives de l'Académie des sciences morales et politiques, 18321848 », Annales de la révolution française, 1975, n. 222, pp. 567-83.

8 For these and following data, Delmas, op. cit. 
These eternal truths were not specific to any philosophical doctrine in particular, and Cousin's philosophy was also referred to as eclectic. Cousin and his associates favoured a position which was « secular and yet not irreligious, liberal and yet not revolutionary »?.

This philosophical stance fulfilled a dual function. On the one hand it defined the general framework for the professional philosophers in the lycées and the University by focussing on the history of philosophy and a spiritualist psychology. This philosophy was taught in the Faculties of letters, which had been separated from the science Faculties since the Napoleonic reforms of 1806-08. Besides providing a new orientation for professional philosophers, Cousin insisted that his spiritualist creed also represented an appropriate basis for the civic spirit of the constitutional regime. Its central principles - the existence of God, free will, and objective standards of good and evil - were considered necessary values for a stable and orderly nation, resting ultimately on the common sense of its citizens. Cousin's doctrine thus defined the unity of the different sections of the Academy as well and its relationship to the state.

The historians belonging to the section for «general and philosophical history» were in a position similar to that of the philosophers. They had close connections to both the University and the political elite. Guizot himself was a central figure of this section, along with Mignet and Thierry ${ }^{10}$. Their work was called 'general and philosophical' because it was distinguished from the specialised historical erudition practised at the Académie des inscriptions et belles-lettres. Much of it was related to historical justifications of the constitutional regime ${ }^{11}$. Just as Cousin had outlined the framework for a more or less official philosophy, Guizot and his associates set the standards for a more liberal view on the history of the French nation as well as for more professional historical research by creating institutions like the Comité des travaux historiques.

The section on morals was concerned with what later came to be called the social question. The first prize contest of the section well illustrates this concern:

\footnotetext{
Which are, according to exact observation of the facts, the elements which in Paris, or in any other big city, compose the part of the population which forms a dangerous class, because of its vices, its ignorance and its misery? Which means could be employed by the Administration, the rich or prosperous men, and the intelligent and laborious workers to improve this deprived and miserable class ? $^{12}$
}

The topic was made public in 1833, but the prize was not discerned because the reports were judged to be insufficient. One mémoire, however, obtained a special fee. Written by an employee of the Parisian prefecture, H.-A. Frégier, it was published under the title Des classes dangereuses de la population des

9 Doris S. Goldstein, 'Official philosophies in France: The Example of Victor Cousin', Journal of Social History, 1, 1967/68, pp. 259-257.

10 On Guizot, see Pierre Rosanvallon, Le moment Guizot, Paris, Gallimard, 1985.

11 Stanley Mellon, The Political Uses of History: A Study of Historians in the French Reastauration, Stanford, Stanford University Press, 1958; Yvonne Knibiehler, Naissance des sciences humaines: Mignet et l' histoire philosophique, Paris, Flammarion, 1973.

12 Académie des sciences morales et politiques, Concours de l'Académie, 1834-1900, Paris, Imprimerie Nationale, 1901, p. 5. 
grandes villes, et des moyens de les rendre meilleures (1840). Similar research was done on topics like public health and epidemics, prostitution, pauperism, the physical and moral state of the working classes, and prison reform ${ }^{13}$.

Members of the section for political economy and statistics also did research of this kind. Villermé, author of the well known Tableau de l'état physique et moral des ouvriers employés dans les manufactures de coton, de laine et de soie (1840), initially belonged to the political economy section. Guizot had commissioned his work after the urban upheavals of 1831 and 1834. Most economists, however, were critical of the protectionist policies of the government. One or two held a chair at the Collège de France or an Ecole de commerce, but the vast majority had few connections with higher education. Propagating liberal economic policies, the economists were active in the Société d'économie politique (1842) and contributed to the Journal des économistes (1841), a monthly review of 'economics and agricultural, manufacturing and commercial questions'. Both the journal and the society were committed to the idea that political economy was a 'practical science'. In their view political economy represented a "set of doctrines beyond which there was little to improve" ${ }^{14}$. The members of the society were mainly publicists and politician-economists, often trained in law, and more frequently related to business circles than to scholarly centres. They formed an increasingly effective lobby, but their efforts to promote the teaching of political economy were successful only after 1870 .

Practically all the work that was done or supported by the Academy rested on two principles. It was, first, marked by a unitary conception of the moral and political sciences. All these studies were defined as moral sciences, founded on a spiritualist anthropology, and as such explicitly opposed to the procedures and the models of the natural sciences. Cousin's spiritualism provided its general orientation and its different branches were generally referred to as philosophical sciences. The central categories of the outlook were summarized in the official Dictionnaire des sciences philosophiques (six volumes, 1844-52). The notion of 'society', for example, is briefly described as based on three conditions: liberty, property and the family. All three conditions rested on the moral nature of man, which was thought to presuppose the 'religious dogmas of providence and a life hereafter ${ }^{15}$. As opposed to this liberal creed, socialism was merely referred to as those doctrines that «directly or indirectly» deny these very conditions. Other oppositional currents, positivism among them, were not even mentioned.

The second principle of the Academic studies was their practical character. They were regarded as directly linked to problems of government and public

${ }_{13}$ On these early forms of social research: Louis Chevalier, Classes laborieuses et classes dangereuses à Paris pendant la première moitié du 19e siècle, Paris, Plon, 1958; William Coleman, Death is a Social Disease. Public Health and Political Economy in Early Industrial France, Madison, University of Wisconsin Press, 1982; Bernard-Pierre Lécuyer, «Demographie, statistique et hygiène public sous la monarchie censitaire », Annales de démographie historique, 1977, pp. 215-45; Bernard-Pierre Lécuyer, «The Statistician's Role in Society: The Institutional Establishment of Statistics in France», Minerva, 1987, pp. 35-55.

14 Quoted in Alain Alcouffe, «The Institutionalization of Political Economy in French Universities: 1819-1896 », History of Political Economy, 21, 1989, p. 322.

15 Dictionnaire des sciences philosophiques, Paris, Hachette, 1844-52, vol. 6, p. 672-73. 
administration, in which the concern for public order prevailed. Haunted by memories of the revolution, the members of the Academy consistently criticised the irresponsible nature of revolutionary theories and deplored the tendency to separate social theorizing from political responsibilities. Instead of devoting themselves to useful and applicable studies, numerous writers and publicists had been «lost in abstractions» or «seduced by utopias». To counter this trend, the task of the Academy was to unite these sciences and to direct them towards a «common centre», toward the study of verités d'application ${ }^{16}$. This theme was vital for nearly all academicians, for statesmen like Guizot, as well as for a researcher as Villermé. It is prominent also in the work of Tocqueville whose criticism of uprooted and irresponsible intellectuals was a critical part of his analysis of the French revolution. Of noble origins and slightly younger than Guizot and Cousin, Tocqueville saw his work as belonging to 'that great science of government, which learns to understand the general movement of society, to judge what passes in the mind of the masses, and to foresee what will result of it ${ }^{17}$. Tocqueville's plea for a new science of government was based on his critique of writers and other men of letters who under the old regime had acquired political influence without having political responsibilities.

The expression 'moral and political sciences', although first used in the circle of the physiocrats in the second half of the eighteenth century, was an apt description of the orientation of the Academy. To speak of moral sciences meant that they were part of moral philosophy in the classical sense of the term and dependent on a general philosophical framework. And the various branches of these moral sciences were practiced in order to contribute to what we would now call policy issues. The alternative expression «social science», coined during the revolutionary turmoil of the 1790s, was consciously avoided, since it was associated with the materialism and the scientism of the revolutionary period, with Condorcet's 'social mathematics' or with Cabanis' physiological science of man, and with the legacy of irresponsible political commitments. The programmatic aim of the Academy was to replace both this tradition and its conservative counterpart by a more liberal outlook. By establishing a new infrastructure for these studies, the moral and political sciences came to be separated from the natural sciences and more closely linked to both the Faculties of law and letters as well as to a variety of governmental agencies. Someone like Auguste Comte who was trained in the natural sciences and a republican, not to speak of socialists and other radical thinkers, remained entirely outside of the circles of the Academy.

\section{THE INVASION OF THE POSITIVE SCIENCES}

After the revolution of 1848 and during the Second Empire (1851-70), the Academy was forced to redefine its role. Confronted with authoritarian interventions by the Bonapartist government, there were conflicts about elections and

16 M. Le Comte Portalis, «Discours sur la marche et les progrès des sciences morales et politiques », Séances et travaux de l'Académie des sciences morales et politiques, 1843, vol. 3, pp. 331-354.

17 Tocqueville, L'ancien régime et la révolution (1856), Paris, Gallimard, 1967, p. 237. 
procedures, and the formal autonomy of the Academy was violated more than once $^{18}$. Certain liberal professors were deprived of their chairs, and in educational matters the Catholic Church was favoured once again. Only when Victor Duruy became Minister of education in 1863 were more liberal policies reintroduced. Following the revolution of 1848 , the growing left wing opposition had equally undermined the confidence of many liberals. In his memoirs of the 1860s, Guizot observed the 'fatal influence' of new doctrines. Whether they were called republican, democratic, socialist, communist, or positivist, all the new ideas, Guizot noted, were opposed the established order. In Guizot's view they had a 'radical vice' in common. While each of them contained a grain of truth, they isolated and exaggerated this up to the point of becoming an 'enormous and detestable error' ${ }^{19}$. No less important for Guizot's discontent with the course of events was the manifestation of a new generation of intellectuals. In the 1860s, Ernest Renan and Hippolyte Taine gained intellectual notoriority by attacking the very principles of the academic orthodoxy. Both men were born in the $1820 \mathrm{~s}$ and had experienced the events of 1848 and the coup d'Etat of 1851 as the end of the dreams of the preceding generation. In the name of a more demanding conception of science, their criticism was especially directed against the metaphysics of Cousin's school. Renan wrote his L'avenir de la science in 1848-49, displaying a religious belief in the sciences and their promise to understand the history of humanity. Trained primarily as a philosopher, Renan deplored Cousin's lack of method, his superficial appeal to common sense and his religious assumptions. Renan turned to historical erudition and soon became a member of the Académie des belles-lettres. Greatly impressed by German scholarship, he advocated historical and philological erudition as a science with a philosophical goal: the science of the products of the human mind ${ }^{20}$. Renan wrote historical studies and critical essays; his Vie de Jésus (1863) provoked a scandal and made him a celebrity.

Taine, also trained as a philosopher, first gained public attention with a devastating polemic, Les philosophes français du XIX $X^{e}$ siècle (1857). The 'official philosophy' taught in the lycées and the university had, according to Taine, contributed next to nothing to the great scientific advances of the century. Philosophy had been reduced to rhetorical exercises and deist morals. Divorced from the analytical and experimental spirit of the sciences, French philosophy had become sterile. Tracing this tradition from the beginning of the nineteenth century (Laromiguière, Maine de Biran) up to Cousin, Taine argued that philosophy should again be allied to the sciences. In the moral sciences one had to proceed in the same way as the naturalists. These sciences were in fact nothing else than a kind of «applied botany that does not deal with plants but with the works of men ». That view, Taine stated, corresponded to the 'general movement' by which the moral sciences and the natural sciences were approximating one another. Every

18 Some anecdotes about these conflicts are provided by Adolphe Lair, L'Institut de France et le Second Empire, Paris, Plon, 1908.

19 François Guizot, Mémoires pour servir à l' histoire de mon temps, Paris, Michel Lévy, 1858-67, vol. 6, pp. 345-46.

20 See especially Ernest Renan, «La métaphysique et son avenir» (1860), in Euvres complètes, Paris, Callmann-Lévy, 1947, vol. 1, p. 680-714. 
science studies 'facts' and investigates its 'causes', no matter if the facts be physical or moral ${ }^{21}$. Taine expressed this view in provocative phrases («vice and virtue are products, like vitriol and sugar ») suspect of the very materialism Cousin had so successfully combated. In De l'intelligence (1870) he outlined a psychology directly opposed to Cousin's philosophical speculation and introspection. In his Histoire de la littérature anglaise (1863) he proposed his famous trinity, la race, le milieu, and le moment, as the explanatory factors for the study of moral phenomena.

The work of Taine and Renan forcefully suggested that the dominant conception of the moral sciences lacked a scientific basis, and owed its authority merely to the fact that it was an official doctrine. Their plea for modern scholarship and scientific study made a lasting impression on the intellectual youth of the 1860s, although the Faculty of letters remained dominated by members of Cousin's regiment for many years to come. The inheritors replied to their critics by reinterpreting or restating Cousin's doctrine. Elme Caro, for example, published a very orthodox defense, L'idée de Dieu et ses nouveaux critiques (1864). More than a decade later he still deplored what he described as 'the invasion of the positive sciences into the moral sciences' ${ }^{\prime 2}$. Paul Janet, like Caro philosophy professor at the Sorbonne, was somewhat more sensitive to new movement. Janet had published a voluminous textbook, Histoire de la philosophie morale et politique (1858), which had won several prizes. He acknowledged the new situation in an essay on La crise philosophique (1865). Whereas spiritualism had had no rival in the first half of the century, it suffered a serious crisis ever since. The spiritualist school, Janet noted, no longer dominated opinion, while the 'spirit of the positive sciences' advanced with 'incalculable speed" ${ }^{23}$. Janet discussed Taine and Renan, and also paid attention to Emile Littré, who had just published his Auguste Comte et la philosophie positive (1863). Littré was the most authoritative defender of positivism after Comte's death, and was known as a philosophically minded érudit and a republican. He had translated the complete works of Hippocrates, was preparing a new dictionary of the French language, and, like Renan, was a member of the Académie des belles-lettres.

Opposition to the Academy of moral and political sciences thus came from different quarters. During the 1860s scholars like Renan, Taine and Littré became the intellectual avant-garde of the day. Coming from the marginal research sector of higher education, they had contacts with a small group of érudits, mainly historians, linguists and philologists, as well as with some representatives of the natural sciences. Renan was a long standing friend of the chemist Marcellin Berthelot, Littré collaborated closely with the biologist Charles Robin on a Dictionnaire de médecine, Taine was well acquainted with several naturalists and medical doctors. Their intellectual ambitions were marked, furthermore, by contacts with writers like Flaubert and the Goncourt brothers. Their struggle for a more autonomous literature, expressed in the doctrine of l'art pour l'art, challenged the Académie

See especially H. Taine, Philosophie de l'art (1865), Paris, Hachette, 1917, chapt. 1.

E. Caro, Problèmes de morale sociale, Paris, Hachette, 1876, p. 4.

23 Paul Janet, La crise philosophique. Mm. Taine, Renan, Littré, Vacherot, Paris, Baillière, 1865, p. 6-7. 
française in a similar way as Renan and Taine had challenged the philosophical academism. This convergence of interests, vividly discussed during regular dinners in the restaurant Magny, occurred largely outside of the official academic structures, and gained a prophetic function during the first years of the Third Republic.

\section{REPUBLICANISM, SCIENCE AND THE UNIVERSITY AFTER 1870}

Many of the changes of the last decades of the nineteenth century were related to the effects of the Franco-Prussian war. Both the military defeat and the Commune had an enormous impact during the first decades of the Third Republic (1870-1940). Daniel Halévy has described the early years of the new republic as the end of the notables. Whereas previous regimes had rested on either conservative or liberal factions of the notables, the Third Republic became a more democratic regime. The parliamentary system became well established, universal male suffrage was instituted in 1884, secularism advanced, and the system of public education expanded. Both the increasing autonomy of various fields and new patterns of recruitment weakened the traditional position of the notables. As Christophe Charle has demonstrated the political, economic and intellectual elites under the Third Republic were more clearly separated from one another than ever before ${ }^{24}$.

The main challenge for the successive republican regimes was to find an answer to both the German challenge and to popular uprisings like the Commune. Educational reform thus became a corner stone of republican politics. The new educational system was designed to integrate larger segments of the population, and to bring them under more direct control of the state. This was realised in fierce struggles with the church. Driven by anti-clerical movements, the expansion of public education was simultaneously seen as a reply to German superiority, since the power of the German Empire was widely held to be based on scientific and educational advance. Expanding the system of public education was thus considered a vital condition for the 'regeneration' of the French nation. Reason and science became fundamental values for the secular regime, which appealed to neither God nor King, and a form of pedagogical idealism became a primary characteristic of French republicanism ${ }^{25}$. Reforms of higher education were an integral part of educational program of the republican administrations. During the 1870s and 1880s the movement for university reform spread through an academic community eager to improve its position ${ }^{26}$. It was promoted by pressure groups like the Association française pour l'avancement des sciences (1872), and the Société de l'enseignement supérieur (1878). This powerful reform movement was

\footnotetext{
Christophe Charle, Les élites de la République (1880-1900), Paris, Fayard, 1987.

Claude Nicolet, L'idée républicaine en France, Paris, Gallimard, 1982, pp. 258, 374.

For French higher education see the contributions by Victor Karady in Jacques Verger (ed.), Histoire des universités en France, Toulouse, Privat, 1986, pp. 261-365; George Weisz, The Emergence of Modern Universities in France, 1863-1914, Princeton, Princeton University Press, 1983, Christophe Charle, La république des universitaires, 1870-1940, Paris, Seuil, 1994.
} 
allied to the republican elite who believed that university reform would serve the needs of the republican state.

The actual reforms, from the end of the 1870s to the beginning of the twentieth century, fundamentally altered the size and the structure of higher education. Stimulated by the introduction of scholarships, the number of university students increased from 10,000 in 1875 to 42,000 in 1914. The teaching corps increased in a similar fashion. The number of university professors rose from 340 (1865) to 750 (1919). Junior staff positions grew at an even faster rate, increasing from 150 (1865) to $660(1919)^{27}$. The expansion had its most significant impact in the Faculties of science and letters. They had had very few students until the late 1870 s, since their role was practically restricted to grading the baccalauréat examination and offering public lectures. Following various reform proposals, the republican administration stimulated the growth of the Faculty system, and also encouraged scholarship and research. Travel grants were made available, junior staff positions were created for young academics, chairs were established for new fields of research. Public lectures for worldly audiences were dropped in favour of teaching full-time students. The Faculties of science and letters were thus transformed into more professional institutions of research, and scholarly publications became a key element in a successful university career. Before 1840, theses for the doctorate of letters were hardly ever longer than 100 pages. After 1880 their vast majority was longer than 300 pages, reaching an average of 510 pages in $1900^{28}$. A thorough monograph based on original research became a precondition for a professorship.

In the relatively short period of a few decades professors in the Faculties of letters and science thus became more numerous, more specialised and more scholarly professionals. Increasingly recruited from intellectual families of the middle classes, they were most often graduates of the selective École normale supérieure. Almost inevitably, their political activities and administrative connections diminished. The number of university professors in the senate and the chamber of deputies decreased significantly. By the end of the century, it had become rare for a university professor to simultaneously pursue a political career ${ }^{29}$. Their public visibility equally diminished. Intellectual journalism, public lecturing and composing elegant essays gave way to more scholarly work and a corresponding life style ${ }^{30}$.

\section{THE TRIPARTITE DIVISION OF FRENCH SOCIAL SCIENCE}

After 1870 the centre of the social sciences shifted rapidly from the Academy of moral and political sciences to the Faculties of the re-formed university. The

\footnotetext{
27 Weisz, op. cit., p. 236 and 318.

28 Victor Karady, «Educational Qualifications and University Careers in Nineteenth Century France », in Robert Fox and George Weisz (eds), The Organization of Science and Technology in France, 1808-1914, Cambridge, Cambridge UP, 1980, 95-124.

29 Christophe Charle, Les élites de la République, op. cit., pp. 410-11.

so Jean-Louis Fabiani, Les philosophes de la République, Paris, Minuit, 1988, pp. 111-118.
} 
Academy lost its prevailing role, the expression 'moral and political sciences' became outdated, and a whole new structure emerged. For the social sciences, as they were now increasingly called, the consequences were twofold. First, the relatively unified field of moral and political sciences split into more autonomous disciplines, each with their own chairs and scholarly journals. Disciplinary social science became the predominant mode of research and teaching, while the Academy of moral and political sciences increasingly became an honorific institution, acting more as the moral consciousness of the nation. Second, these social science disciplines gained a far greater degree of autonomy vis-à-vis governmental agencies than the Academy had ever had. Professional autonomy, in its different guises - conceptually, socially and institutionally - was the main preoccupation of the representatives of the new disciplines.

This characteristic, which needs more systematic elaboration, holds true for the philosophers who became the university pioneers in psychology and sociology (Ribot, Espinas, Durkheim), it also applies to many of the economists who introduced political economy in the Faculty of law. But these conflicts between established academicians and younger representatives of emerging university disciplines were in a more structural sense not specific for France. In other countries there was a structural opposition as well between a younger generation of university professors and an older generation of reform oriented social science practitioners. Although there were no national academies similar to the ones in France, there were structural equivalents of the Académie des sciences morales et politiques, most often national associations like the (British) National Association for the Promotion of Social Science (1857), its American counterpart, the American Social Science Association (1867) and the German Verein für Socialpolitik (1873). From this perspective, the most fundamental change for the social sciences at the end of the nineteenth century was the shift from relatively unified national social science associations with a predominantly practical concern to a more differentiated structure of more scholarly university disciplines, organised around university chairs, scholarly journals and professional associations, all of them on a disciplinary basis.

If this general characteristic is at least plausible, it is no less important to observe that this process took different forms in various national contexts. In France, the new social sciences came to form a relatively stable, tripartite structure $^{31}$. Henceforth political science was primarily taught and practised at the Ecole libre des sciences politiques (1871), a professional school, close to the state apparatus, which trained many generations of upper-level civil servants, but which has remained peripheral in a scientific sense. At the opposite pole was the Faculty of letters, which trained people mainly for intellectual careers in teaching and research. These disciplines, the sciences humaines, among them philosophy and history, represented the intellectual pole of the spectrum and gradually came to include psychology, sociology and anthropology. Economics, the third group, was situated in between the professional school for political science and the Faculty of

For a more elaborate analysis see Johan Heilbron, 'The Tripartite Division of French Social Science', in Peter Wagner, Bjorn Wittrock and Richard Whitley (eds), Discourses on Society. The Shaping of the Social Sciences Disciplines, Dordrecht/Boston, Kluwer Academic Publishers, 1991, pp. 73-92. 
letters, since it was instituted in the Faculty of law and was bound to juridical training.

Reconsidering the institutionalization of sociology from the perspective briefly outlined in this article, one can only conclude that sociology, from its earliest beginnings, has occupied a peculiar position. What Auguste Comte conceived as the social science par excellence, emerged outside of the academic institutions and in opposition to the organized field of moral and political studies. The idiom of the 'moral and political sciences' designated a different intellectual and social space from those who used a vocabulary derived from the adjective 'social', preferring to speak of 'social science', the 'social' question, 'socialism' or 'sociology'. This curious science of human society, with the awkward, even barbarous name of sociology, entered French institutions of higher learning only after it had gained scholarly acceptance elsewhere, notably through the work of Herbert Spencer. This was precisely the grief Emile Durkheim formulated in his Latin thesis, which expressed a factual description as well as a formidable working program:

\begin{abstract}
... nous avons pris l'habitude de considérer la science sociale comme étrangère à nos mœurs et à l'esprit français. Le fait que d'illustres philosophes qui ont tout récemment écrit sur ces matières ont jeté leur éclat et en Angleterre et en Allemagne [...] nous a fait oublier que cette science est a d'abord pris naissance chez nous ${ }^{32}$.
\end{abstract}

Centre de sociologie européenne (CSE), Paris

\& Université d'Utrecht

heilbron@msh-paris.fr

32 Émile Durkheim, Montesquieu et Rousseau, précurseurs de la sociologie (1892), Paris, Rivière, 1966 , p. 25. 